\title{
Interleukin-35 Suppresses the Antitumor Activity of T Cells in Patients with Non- Small Cell Lung Cancer
}

\author{
Hong-Min Wang ${ }^{a} \quad$ Xiao-Hong Zhang ${ }^{b} \quad$ Ming-Ming Feng ${ }^{a} \quad$ Yan-Jun Qiao \\ Li-Qun Yea Jing Chen $^{a} \quad$ Fei-Fei Fan ${ }^{a}$ Lin-Lin Guo
}

aDepartment of Respiratory Medicine, First Affiliated Hospital of Zhengzhou University, Zhengzhou, Henan Province, 'bepartment of Respiratory Medicine, Zhengzhou Central Hospital Affiliated to Zhengzhou University, Zhengzhou, Henan Province, China

\section{Key Words}

Non-small cell lung cancer $\bullet$ Interleukin-35 $\bullet$ T cells $•$ Antitumor activity $\bullet$ Immunoregulation

\begin{abstract}
Background/Aims: Interleukin (IL)-35 has immunosuppressive functions in autoimmune diseases, infectious diseases, and certain cancers. However, few studies have focused on its immunoregulatory activity in non-small cell lung cancer (NSCLC). Thus, we investigated the role of IL-35 in the pathogenesis of this disease. Methods: A total of 66 NSCLC patients and 21 healthy individuals were enrolled. IL-35 expression in peripheral blood and bronchoalveolar lavage fluid (BALF) was measured. The modulatory functions of IL-35 on purified CD4 ${ }^{+}$and $\mathrm{CD} 8^{+} \mathrm{T}$ cells from NSCLC patients were investigated in direct and indirect coculture systems with NSCLC cell lines. Results: IL-35 expression was significantly increased in BALF from the tumor site, but not in the peripheral blood of NSCLC patients. IL-35 did not affect the bioactivity including proliferation, cytokine production, cell cycle, and cellular invasion of NSCLC cells. It suppressed responses from type $1 \mathrm{~T}$ helper (Th1) and Th17 cells but elevated the regulatory $\mathrm{T}$ cell response in cultured CD4 ${ }^{+} \mathrm{T}$ cells from NSCLC patients, and reduced cytokine-mediated CD4 ${ }^{+} \mathrm{T}$ cells cytotoxicity to NSCLC cells. Moreover, IL-35 also inhibited cytotoxic gene expression in $\mathrm{CD}^{+} \mathrm{T}$ cells from NSCLC, reducing their cytolytic and noncytolytic functions. Conclusion: The results of this study suggest that IL-35 contributes to the dysfunction/exhaustion of T cells and limited antitumor immune responses in NSCLC.

(C) 2018 The Author(s)

Published by S. Karger AG, Basel
\end{abstract}

\section{Introduction}

Lung cancer, which can be divided into small cell lung cancer and non-small cell lung cancer (NSCLC), is the leading cause of cancer-related deaths worldwide [1, 2]. NSCLC accounts for approximately $85 \%$ of lung malignancies [3], and nearly 75\% of NSCLC cases are 
diagnosed in the advanced stage with an estimated 5-year survival rate of $18 \%$ in the United States [4]. Immune checkpoint inhibitors have emerged as powerful new therapeutic tools for advanced NSCLC $[5,6]$. However, although antibodies against programmed death-1 and cytotoxic $\mathrm{T}$ lymphocyte associated protein 4 may improve outcomes in a metastatic setting, the overall response rate is less than $45 \%$ even in highly molecularly selected patients [5-7]. This is partly due to the complex strategies adopted by tumor cells to escape the cytotoxicity of the immune system. Thus, it is important to better understand the underlying molecular mechanisms of immune surveillance and by which cancer cells acquire the ability to evade eradication by the immune system.

Interleukin (IL)-35 belongs to the IL-12 family of cytokines. It is a heterodimer cytokine comprised of the Epstein-Barr virus-induced gene 3 and IL-12 p35 subunit $[8,9]$. IL-35 is mainly produced by $\mathrm{CD}^{+} \mathrm{CD} 25^{+} \mathrm{FoxP} 3^{+}$regulatory $\mathrm{T}$ cells (Tregs) [8] and IL-35-expressing regulatory B cells [10], and is required for the immunosuppressive activity of Tregs . IL-35 has anti-inflammatory and immunoregulatory properties $[9,11]$, and inhibits angiogenesis through different signaling pathways [12]. It also plays pivotal roles in the pathogenesis of cancers, as it promotes the growth of cancer cells through the enhancement of proliferation and angiogenesis, inhibition of apoptosis [13-15], and limitation of anti-tumor T cells immunity [16]. In addition, elevated IL-35 levels are also associated with cancer progression, aggressiveness, and recurrence [17-20]. A previous study also demonstrated that IL-35 overexpression correlated with a poor prognosis in patients with NSCLC [21]. However, the role of IL-35 in NSCLC has not been fully elucidated.

Due to the immunosuppressive potential of IL-35 in chronic infection and cancer, we hypothesized that it inhibits the antitumor activity of $\mathrm{T}$ cells and contributes to immune evasion in NSCLC. To test this possibility, the effects of recombinant IL-35 stimulation on $\mathrm{CD}^{+} / \mathrm{CD}^{+} \mathrm{T}$ cells and NSCLC cell lines were investigated in vitro.

\section{Materials and Methods}

\section{Enrolled subjects}

A total of 66 patients with pathologically confirmed NSCLC were enrolled in this study. All patients were hospitalized in the Department of Respiratory Medicine of the First Affiliated Hospital of Zhengzhou University (Henan Province, China) between February 2015 and March 2016. Six patients were concurrently suffering from chronic obstructive pulmonary disease (COPD). Patients with pneumonia, autoimmune disorders (including asthma), or who were immunocompromised were excluded from the study. No patients received surgery, chemotherapy, or radiotherapy before the study. The diagnosis was made according to National Comprehensive Cancer Network Clinical Practice Guidelines in Oncology: Non-Small Cell Lung Cancer Version 1.2015. The tumor-node- metastasis (TNM) stages were evaluated according to the American Joint Committee on Cancer/Union for International Cancer Control TNM classification (7th ed.). For normal controls (NCs), 21 sex- and age-matched healthy individuals were enrolled, none of whom had asthma or COPD. The clinical characteristics of the enrolled subjects are shown in Table 1. The study protocol was approved by the ethics committee of the First Affiliated Hospital of Zhengzhou University, and written informed consent was obtained from each enrolled subject.

\section{Isolation of serum and peripheral blood mononuclear cells}

A total of $5 \mathrm{~mL}$ coagulant peripheral blood and $10 \mathrm{~mL}$ EDTA-anticoagulant peripheral blood were collected from each enrolled subjects. Serum samples underwent centrifugation at $12,000 \times g$ for $10 \mathrm{~min}$ from coagulant peripheral bloods. Peripheral blood mononuclear cells were isolated using Ficoll-Hypaque (Sigma, St. Louis, MO, USA) density gradient centrifugation from anticoagulant peripheral bloods.

\section{Preparation of bronchoalveolar lavage fluid}

In NSCLC patients, local anesthesia was firstly performed by injection with $2 \mathrm{~mL}$ of $2 \%$ lidocaine in the lung section through the biopsy hole with a thin silicone tube. The top of the bronchofiberoscope closely wedged into the opening of the subsegmental bronchus. Then, $50 \mathrm{~mL}$ sterilized saline was rapidly injected 


\section{Cellular Physiology Cell Physiol Biochem 2018;47:2407-2419 \begin{tabular}{l|l|l} 
and Biochemistry 10.1159/000491615 & $\begin{array}{l}\text { C } 2018 \text { The Author(s). Published by S. Karger AG, Basel } \\
\text { www.karger.com/cpb }\end{array}$
\end{tabular} \\ Wang et al.: IL-35 Suppresses T Cells Activity in NSCLC}

through the biopsy hole; this was repeated four times. The lavage fluid was immediately recovered with $100 \mathrm{mmHg}$ negative pressure, with a recovery rate between $40 \%$ and $60 \%$. Bronchoalveolar lavage fluid (BALF) was filtered with double sterilized gauze and the total amounts were recorded. BALF was centrifuged at $1,200 \times g$ for $10 \mathrm{~min}$ at $4^{\circ} \mathrm{C}$. The supernatants were harvested and kept at $-70^{\circ} \mathrm{C}$ for subsequent experiments, while cellular precipitations were washed twice and cultured in RPMI 1640 supplemented with $10 \%$ fetal bovine serum (FBS) at a concentration of $10^{6} / \mathrm{mL}$.

\section{Purification of $C D 4^{+}$and $C D 8^{+}$T cells}

$\mathrm{CD}^{+}$and $\mathrm{CD}^{+} \mathrm{T}$ cells were purified using the human $\mathrm{CD}^{+} \mathrm{T}$ Cell and human CD8 ${ }^{+} \mathrm{T}$ Cells Isolation Kits (Miltenyi Biotech, Bergisch Gladbach, Germany), respectively, according to the manufacturer's instructions. The purity of enriched cells was $>95 \%$, as determined by flow cytometry analysis.

\section{Transfection}

The NCI-H520 lung squamous carcinoma cell line and A549 lung adenocarcinoma cell line were transfected with pcDNA3.1-HLA-A*0201 [22] using Lipofectamine 2000 (Invitrogen Life Tech, Carlsbad, CA, USA). Transfected cells were incubated at $37^{\circ} \mathrm{C}$ and $5 \% \mathrm{CO}_{2}$. G418 antibiotic (final concentration, $6.5 \mathrm{mg} / \mathrm{mL}$ ) was added to the culture medium to select stable transfectants. Stably transfected cells were used for all subsequent studies.
Table 1. Clinical characteristics of enrolled subjects

\begin{tabular}{|c|c|c|}
\hline & NSCLC & $\mathrm{NC}$ \\
\hline Case (n) & 66 & 21 \\
\hline Gender (male/female) & $43 / 23$ & $13 / 8$ \\
\hline Age (years) & $58.2 \pm 11.7$ & $55.3 \pm 9.8$ \\
\hline COPD history & $6(9.09 \%)$ & $0(0.00 \%)$ \\
\hline \multicolumn{3}{|l|}{ Smoking history } \\
\hline$>10$ years & 37 & 6 \\
\hline$<10$ years & 18 & 6 \\
\hline none & 11 & 9 \\
\hline \multicolumn{3}{|l|}{ Histology } \\
\hline SCC & $36(54.5 \%)$ & N.A. \\
\hline AC & $30(45.5 \%)$ & N.A. \\
\hline \multicolumn{3}{|l|}{ Differentiation } \\
\hline Well & $8(12.1 \%)$ & N.A. \\
\hline Moderate & $41(62.1 \%)$ & N.A. \\
\hline Poor & $17(25.8 \%)$ & N.A. \\
\hline \multicolumn{3}{|l|}{ TNM stage } \\
\hline I & $14(21.2 \%)$ & N.A. \\
\hline II & $20(30.3 \%)$ & N.A. \\
\hline III & $21(31.8 \%)$ & N.A. \\
\hline IV & $11(16.7 \%)$ & N.A. \\
\hline
\end{tabular}

\section{Cell culture and stimulation}

Cells were stimulated with recombinant human IL-35 (1 ng/mL; Peprotech, Rocky Hill, NJ, USA) for $6 \mathrm{~h}$, washed twice, and incubated for another $48 \mathrm{~h}$. In certain experiments, $10^{5}$ purified $\mathrm{CD} 4^{+} \mathrm{T}$ cells or $\mathrm{CD}^{+} \mathrm{T}$ cells from HLA-A2-restricted NSCLC patients were stimulated with recombinant IL-35 for $6 \mathrm{~h}$. Cells were washed twice to remove IL-35 and were cocultured in direct or indirect contact with $5 \times 10^{5}$ of stably transfected NCI-H520 cells or A459 cells in the presence of anti-CD3/CD38 (eBioscience, San Diego, CA, USA) for $48 \mathrm{~h}$ as previously described [23]. Cells and supernatants were harvested for further studies.

\section{Cell proliferation assay}

Cellular proliferation was measured using the Cell Counting Kit-8 (CCK-8; Beyotimes, Wuhan, Hubei Province, China) according to the manufacturer's instructions.

\section{Flow cytomtery}

Cells were trypsinized after IL-35 stimulation, and $5 \mu \mathrm{L}$ propidium iodide (PI, Beyotime Biotech) was added for a $10 \mathrm{~min}$ incubation at room temperature in the dark. The cell cycle was analyzed with FACSCalibur flow cytometer (BD Biosciences Immunocytometry Systems, San Jose, CA, USA).

\section{Transwell invasion assay}

The invasive activity of NCI-H520 cells and A549 cells was measured using 24-well Transwell chambers (Corning Costar, Corning, NY, USA) containing a polycarbonate membrane ( $8 \mu \mathrm{m}$ pore size). The polycarbonate membrane surface was covered with $50 \mu \mathrm{L}$ of Matrigel (1: 6 dilution; BD Bioscience, San Jose, CA, USA). A549 cells were suspended in $200 \mu \mathrm{L}$ serum-free RPMI 1640 and seeded into the upper chamber, whereas $600 \mu \mathrm{L}$ RPMI 1640 containing 10\% of FBS was added into the lower chamber. Cells that passed through the membrane were stained with $0.1 \%$ crystal violet for $20 \mathrm{~min}$ at room temperature after a 48 -h 


\section{Cellular Physiology Cell Physiol Biochem 2018;47:2407-2419 \begin{tabular}{l|l} 
and Biochemistry Published 1159/000491615 & $\begin{array}{l}\text { (c) } 2018 \text { The Author(s). Published by S. Karger AG, Basel } \\
\text { www.karger.com/cpb }\end{array}$ \\
\hline
\end{tabular}}

Wang et al.: IL-35 Suppresses T Cells Activity in NSCLC

incubation. Each experiment was performed independently five times. The cells numbers in five random fields were calculated using the Olympus BX51 microscope (Olympus, Tokyo, Japan).

Enzyme-linked immunosorbent assay

Cytokine production in either the serum or supernatants of cultured cells was measured using commercial enzyme-linked immunosorbent assay (ELISA) kits (CusaBio, Wuhan, Hubei Province, China) according to the manufacturer's instructions.

\section{Cytokine assay}

The cytokine levels of interferon gamma (IFN- $\gamma$ ), IL-1 $\beta$, IL-6, and tumor necrosis factor alpha (TNF- $\alpha$ ) in the cell culture supernatants were examined with the Human Proinflammation 7-Plex Base Kit (Meso Scale Discovery, Rockville, MD, USA) using the SECTOR Imager (Meso Scale Discovery) according to the manufacturer's instructions.

\section{Real-time polymerase chain reaction (RT-PCR)}

Total RNA was isolated from cultured cells using Trizol (Invitrogen) according to the manufacturer's instructions. RNA was reverse transcribed using Moloney murine leukemia virus reverse transcriptase (TaKaRa Bio, Dalian, Liaoning Province, China) with oligo(dT) primers. Real-time PCR was performed using SYBR Green Premix Ex Taq (TaKaRa Bio) according to the manufacturer's instructions. The primer sequences were previously described [24-26]. Relative gene expression was quantified by the $\Delta \Delta C_{T}$ method using 7500 System Sequence Detection software (Applied Biosystems, Foster, CA, USA).

\section{Cytotoxicity assay}

The cytotoxicity of $\mathrm{CD} 4^{+} \mathrm{T}$ and $\mathrm{CD} 8^{+} \mathrm{T}$ cells was determined by calculating the lactate dehydrogenase (LDH) expression in the supernatants of the cocultured systems. LDH level was measured using the LDH Cytotoxicity Assay Kit (Beyotime) according to the manufacturer's instructions. LDH expression in A549 cells was determined to be low-level control, whereas LDH expression in Triton X-100-treated A549 cells was determined to be high-level control. The resulting value corresponding to the percentage of cell death was calculated in the following equation: (experimental value - low control)/(high control - low control) $\times$ $100 \%$ [23].

\section{Statistical analyses}

All data were analyzed using SPSS 19.0 Version for Windows (SPSS, Chicago, IL, USA). Student's $t$-test was used for comparisons between two groups. Paired $t$-test was used for comparisons prior to and post stimulation. One-way analysis of variance (ANOVA) and Student-Newman-Keuls (SNK) test were used for comparisons among groups. All tests were two tailed, and $P$ values less than 0.05 were considered statistically significant.

\section{Results}

\section{IL-35 expression was increased in BALF from the tumor site in NSCLC patients}

We screened IL-35 expression in the peripheral bloods and BALF from NSCLC patients. As shown in Fig. 1A, there were no significant differences in serum IL-35 concentration between the NCs $(38.51 \pm 13.87 \mathrm{pg} / \mathrm{mL})$ and NSCLC patients $(35.11 \pm 14.13 \mathrm{pg} / \mathrm{mL} ; P=$ 0.337 , Student's $t$-test). There was also no remarkable difference in serum IL-35 expression between patients with squamous carcinoma (SCC) and adenocarcinoma (AC) $(33.79 \pm 14.32$ pg $/ \mathrm{mL}$ vs. $36.69 \pm 13.98 \mathrm{pg} / \mathrm{mL} ; P=0.411$, Student's $t$-test; Fig. $1 \mathrm{~B})$. Moreover, there were no significant differences among patients with well, moderately, and poorly differentiated tumors $(P=0.222$, one-way ANOVA; Fig. 1C). However, serum levels of IL-35 level from TNM stage IV patients $(44.99 \pm 12.47 \mathrm{pg} / \mathrm{mL})$ revealed robust elevation compared with those from stage I patients $(29.63 \pm 14.16 \mathrm{pg} / \mathrm{mL} ; P=0.0094$, SNK test; Fig. 1D) and stage II patients (33.45 $\pm 12.90 \mathrm{pg} / \mathrm{mL}, P=0.023$, SNK test; Fig. 1D). Among patients with AC, 14 ( 4 in stage I, 5 in stage II, 4 in stage III, and 1 in stage IV) were tested for epidermal growth 
factor receptor (EGFR) mutation. A total of 4 of the 14 patients had EGFR mutation. There was no remarkable difference in serum IL-35 concentration between patients with and without EGFR mutation $(33.63 \pm 11.25 \mathrm{pg} / \mathrm{mL}$ vs. $27.31 \pm 8.77 \mathrm{pg} / \mathrm{mL} ; P=0.280$, Student's $t$-test; Fig. 1E). A total of 44 patients underwent bronchoscopy, and BALF was harvested from the tumor sites. Meanwhile, BALF from nontumor sites was only collected from 29 of NSCLC patients due to the intolerance of the other 15 patients. Among these 29 patients, 4 had TNM stage I disease, 10 had stage II, 9 had stage III, and 6 had stage IV disease. As expected, IL-35 expression in BALF from tumor sites was remarkably increased compared with that from nontumor sites $(69.24 \pm 10.66 \mathrm{pg} / \mathrm{mL} v s .60 .10 \pm 25.23 \mathrm{pg} / \mathrm{mL}, P=0.036$, Student's $t$-test; Fig. 2A). Moreover, we also made a paired comparison of IL-35 expression in BALF from nontumor and tumor sites and found that IL-35 expression in 29 BALFs from tumor sites was higher than that in BALFs from nontumor sites $(P=0.049$, paired $t$-test; Fig. 2B). However, there were no significant differences between patients with SCC $(n=25)$ and AC $(\mathrm{n}=19)(P=0.264$, Student's $t$-test; Fig. $2 \mathrm{C})$ or among patients with different grade of differentiation ( $P=0.318$, one-way ANOVA; Fig. 2D). Similar to the trend of serum IL-35 changes, the expression of IL-35 in BALF from TNM stage IV patients $(n=8,81.69 \pm 10.81$ $\mathrm{pg} / \mathrm{mL})$ was also robustly elevated compared with stage I $(\mathrm{n}=10,63.11 \pm 7.68 \mathrm{pg} / \mathrm{mL}, P=$ 0.0006 , SNK test; Fig. 2E), stage II ( $\mathrm{n}=14,67.11 \pm 7.46 \mathrm{pg} / \mathrm{mL}, P=0.0013$, SNK test; Fig. $2 \mathrm{E})$, and stage III patients ( $\mathrm{n}=12,68.55 \pm 10.11 \mathrm{pg} / \mathrm{mL}, P=0.013$, SNK test; Fig. 2E). There was also no remarkable difference in serum BALF IL-35 expression between patients with and without EGFR mutation $(73.15 \pm 8.27 \mathrm{pg} / \mathrm{mL}$ vs. $68.09 \pm 8.30 \mathrm{pg} / \mathrm{mL}, P=0.323$, Student's $t$-test; Fig. 2F).

\section{IL-35 did not directly affect the bioactivity of NCI-H520 and A549 cells}

A density of $5 \times 10^{5}$ of NCI-H520 or A549 cells, which were stably transfected with HLAA2*0201-expressing plasmid, were stimulated with IL-35 (1 $\mathrm{ng} / \mathrm{mL}$ ) for $6 \mathrm{~h}$, and then incubated for another $48 \mathrm{~h}$ after being washed twice. Cells were harvested for cell proliferation assays, and supernatants were collected forcytokineproduction analyses. CCK- 8 results revealed that cell proliferation did not significantly change in NCI-H520 and A549 cells in the presence or absence of IL-35 stimulation $(P>0.05$, Student's $t$-test; Fig. 3A). Proinflammatory cytokine production by both cells, including IFN- $\gamma(P>0.05$, Student's $t$-test; Fig. 3B), IL-1 $\beta$ ( $P$ $>0.05$, Student's $t$-test; Fig. $3 \mathrm{C})$, IL-6 $(P>0.05$, Student's $t$-test; Fig. 3D), and TNF- $\alpha(P>0.05$, Student's $t$-test; Fig. $3 \mathrm{E}$ ) was not affected by IL-35 treatment. Flow cytometry was performed to assess the percentage of cells in different cell cycles. Representative staining by PI of NCI-H520 and A549 cells for cell cycle analysis is shown in

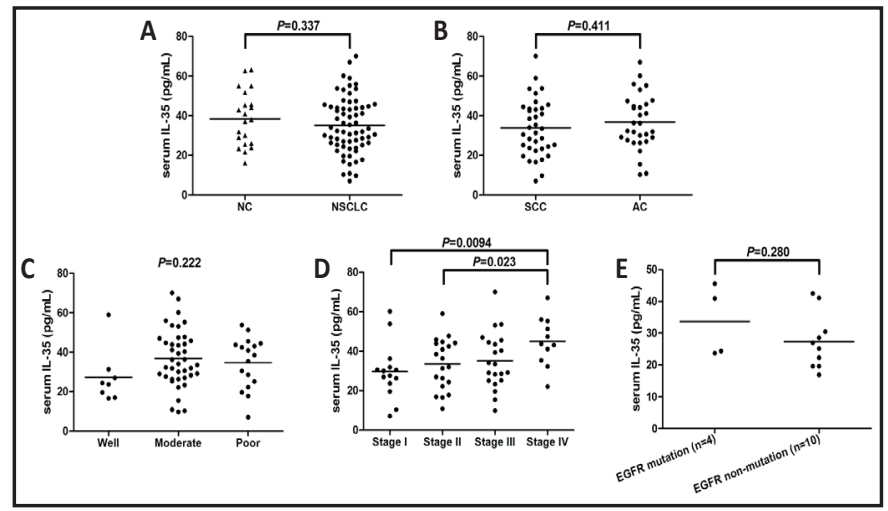

Fig. 1. Serum interleukin (IL)-35 expression in normal controls (NCs) and patients with non-small cell lung cancer (NSCLC). (A) There was no significant difference in serum IL-35 expression between NC $(n=21)$ and NSCLC patients $(n=66)$. (B) There was also no remarkable difference in serum IL-35 level between patients with squamous carcinoma (SCC) $(\mathrm{n}=36)$ and adenocarcinoma (AC) $(n=30)$. (C) There were no notable differences in serum IL35 concentration among well differentiated $(n=8)$, moderately differentiated $(n=41)$, and poorly differentiated $(n=17)$ tumors. (D) Serum IL-35 level was significantly elevated in stage IV ( $\mathrm{n}=$ 11) NSCLC patients than in stage I $(n=14)$ and stage II $(n=20)$ patients, but it was comparable with IL-35 level in stage III ( $\mathrm{n}=$ 21) patients. (E) There was no remarkable difference in serum IL35 concentration between patients with $(n=4)$ and without $(n=$ 10) EGFR mutation. 


\section{Cellular Physiology Cell Physiol Biochem 2018;47:2407-2419 \begin{tabular}{l|l} 
DOI: 10.1159/000491615 & $\begin{array}{l}\text { O 2018 The Author(s). Published by S. Karger AG, Basel } \\
\text { www.karger.com/cpb }\end{array}$
\end{tabular} \\ Wang et al.: IL-35 Suppresses T Cells Activity in NSCLC}

Fig. 3F. There were no significant differences in the percentage of NCI-H520 $(P>0.05$, Student's t-test; Fig. 3G) or A549 cells (data not shown) in the G1, S, or G2 stage. The invasion of NCI-H520 and A549 cells was investigated using the Transwell assay. IL-35 stimulation failed to influence tumor cell invasion (Fig. 3H), which presented as comparable cell numbers passing through the membrane in both cells with or without IL-35 stimulation $(P>$ 0.05 , Student's $t$-test; Fig. 3I).

\section{IL-35 suppressed the function} of $C D 4^{+} T$ cells purified from NSCLC patients

A density of $2 \times 10^{5} \mathrm{CD}^{+}$ $\mathrm{T}$ cells purified from both the peripheral blood and BALF of HLA-A2-restricted NSCLC patients (including 11 with SCC and 9 with AC) were stimulated with recombinant IL-35 for $6 \mathrm{~h}$. Among these 20 patients, 3 had TNM stage I, 7 had stage II, 5 had stage III, and 5 patients had stage IV disease. Cells $\left(10^{5}\right)$ were harvested, and the mRNA expression of T-bet, FoxP3, and ROR $\gamma \mathrm{t}$ was measured by real-time PCR. Cytokine production in the cultured supernatants, including IFN- $\gamma$, IL-10, and IL-17 was measured by ELISA. T-bet mRNA expression was significantly reduced in $\mathrm{CD} 4^{+} \mathrm{T}$ cells from BALF in response to IL-35 stimulation $(P<0.0001$, paired $t$-test; Fig. $4 \mathrm{~A})$, but did not change remarkably in $\mathrm{CD} 4^{+} \mathrm{T}$ cells from peripheral blood with or without IL-35 stimulation $(P=0.912$, paired $t$-test; Fig. 4A). In contrast, FoxP3 mRNA expression was elevated in CD4 ${ }^{+} \mathrm{T}$ cells from both peripheral blood and BALF in response to IL-35 stimulation $(P=0.013$ and $P=0.0018$, respectively, paired $t$-test; Fig. 4B). ROR $\gamma \mathrm{t}$ mRNA expression was decreased in $\mathrm{CD} 4^{+} \mathrm{T}$ cells from BALF with IL-35 treatment $(P<0.0001$, paired $t$-test; Fig. 4C). There was also a reduced trend of ROR $\gamma$ t mRNA expression in $\mathrm{CD}^{+} \mathrm{T}$ cells from peripheral blood, but this difference was not statistically significant $(P=0.066$, paired $t$-test; Fig. $4 \mathrm{C})$. Cytokine production in the supernatants had a trend similar to that of the mRNA expression of transcriptional factors. IFN $-\gamma$ expression was decreased in the supernatants of cultured CD $4^{+} \mathrm{T}$ cells from BALF with IL-35 treatment $(P=0.0004$, paired $t$-test; Fig. 4D), but IL-35 stimulation did not affect IFN- $\gamma$ production by $\mathrm{CD} 4^{+} \mathrm{T}$ cells from peripheral blood $(P=0.244$, paired $t$-test; Fig. 4D). IL-10 concentration was increased in the supernatants of $\mathrm{CD} 4^{+} \mathrm{T}$ cells from both peripheral blood and BALF with IL-35 stimulation $(P=0.072$ and $P=0.0043$, respectively, paired $t$-test; Fig. $4 \mathrm{E})$, whereas IL-17 level was decreased in response to IL-35 treatment $(P=0.015$ and $P=$ 0.0018 , respectively, paired $t$-test; Fig. $4 \mathrm{~F}$ ). Another $10^{5}$ of $\mathrm{CD}^{+} \mathrm{T}$ cells were washed twice after stimulation and cocultured in direct or indirect contact with stably transfected NSCLC cell lines. CD4 ${ }^{+} \mathrm{T}$ cells from patients with SCC were cocultured with NCI-H520 cells, whereas $\mathrm{CD} 4{ }^{+} \mathrm{T}$ cells from patients with AC were cocultured with A549 cells. The supernatants were harvested $48 \mathrm{~h}$ post-coculture. The cytotoxicity of target NSCLC cell lines was investigated by measuring LDH release in the supernatants. Decreased cytotoxicitiy was observed in both 


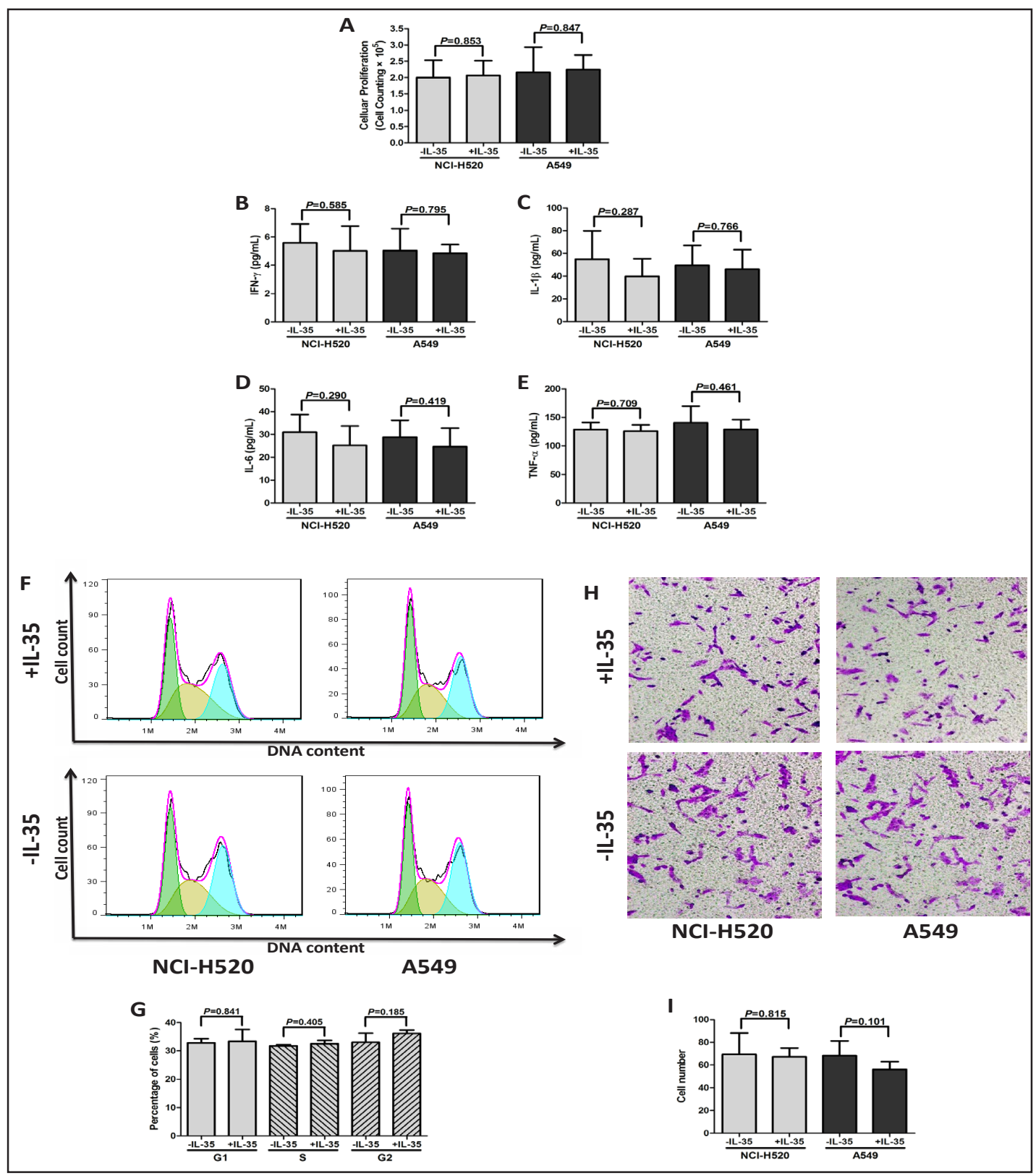

Fig. 3. Effects of interleukin (IL)-35 on the activity of non-small cell lung cancer (NSCLC) cell lines. Squamous carcinoma cell line NCI-H520 cells and adenocarcinoma cell line A549 cells were stably transfected with pcDNA3.1-HLA-A*0201. Stably transfected cells were stimulated with recombinant IL-35 for 6 h. Cells and supernatants were harvested for further studies. (A) Cell proliferation was measured using Cell Counting Kit-8 (CCK-8). The CCK-8 results revealed that IL-35 did not affect cell proliferation in NCI-H520 or A549 cells. Cytokine production in the supernatants, including (B) interferon- $\gamma$ (IFN- $\gamma$ ), (C) IL-1 $\beta$, (D) IL-6, and (E) tumor necrosis factor- $\alpha$ (TNF- $\alpha$ ), was measured by enzyme-linked immunosorbent assay (ELISA). There were no remarkable differences prior to and post IL-35 stimulation in NCI-H520 or A549 cells. Cell cycle analysis was performed by flow cytometry. Representative PI staining of NCI-H520 and A549 cells with or without IL-35 stimulation is shown in (F). The $\mathrm{x}$-axis presents DNA content, while y-axis presents cell count. (G) there were no significant differences in cells in the G1, S, and G2 stage prior to and post IL-35 stimulation in NCI-H520 cells. (H) Representative tumor invasion by the Transwell assay is shown in NCI-H520 and A549 cells with or without IL-35 stimulation. (I) There were no differences in invasion cell numbers prior to and post IL-35 stimulation in NCI-H520 and A549 cells. 
direct and indirect coculture systems in response to IL-35 stimulation, which manifested as a decreased cell death with IL-35 treatment $(P<0.05$, paired $t$-test; Fig. 5A, B). In addition, IL-35 stimulation reduced IFN- $\gamma$ production in the supernatants in both direct and indirect coculture systems of $\mathrm{CD} 4^{+} \mathrm{T}$ cells purified from either peripheral blood $(P<0.01$, paired $t$-test; Fig. 5C) or BALF ( $P<0.01$, paired $t$-test; Fig. 5D). TNF- $\alpha$ was also downregulated in $\mathrm{CD}^{+} \mathrm{T}$ cells when directly cocultured with NSCLC cell lines $(P<0.01$, paired $t$-test; Fig. 5E, F). There were also consistent decreased trends of indirect contact culture system of either peripheral or BALF $\mathrm{CD} 4^{+} \mathrm{T}$ cells, but the difference in peripheral $\mathrm{CD} 4^{+} \mathrm{T}$ cells coculture system did not achieve significance $(P=0.059$, paired $t$-test; Fig. 5E).

\section{IL-35 suppressed the function of CD8 ${ }^{+}$T cells purified from NSCLC patients}

A density of $2 \times 10^{5}$ of $\mathrm{CD}^{+} \mathrm{T}$ cells purified from the same HLA-A2 -restricted NSCLC patients were stimulated with recombinant IL-35 for $6 \mathrm{~h}$. Then $10^{5}$ of CD8 ${ }^{+} \mathrm{T}$ cells were harvested and the mRNA expression of granzyme B, granulysin, and perforin was measured by real-time PCR. IL-35 stimulation significantly reduced the mRNA expressions of granzyme $\mathrm{B}$, granulysin, and perforin in $\mathrm{CD}^{+} \mathrm{T}$ cells purified from both peripheral blood and BALF $(P<$ 0.05 , paired $t$-test; Fig. $6 \mathrm{~A}-\mathrm{C}$ ). Moreover, another $10^{5}$ of $C D 8^{+} \mathrm{T}$ cells were washed twice poststimulation and were the cocultured with stably transfected NSCLC cell lines in the direct and indirect coculture systems. Similar to the coculture CD4 ${ }^{+} \mathrm{T}$ cell system, $\mathrm{CD} 8^{+} \mathrm{T}$ cells from SCC patients were cocultured with NCI-H520 cells, whereas CD8 ${ }^{+} \mathrm{T}$ cells from AC patients were cocultured with A549 cells. Supernatants were harvested 48 h post-coculture for further analyses. Approximate $50 \%$ of target cell deaths were found in the direct contact coculture system with both peripheral and BALF CD8 ${ }^{+} \mathrm{T}$ cells (Fig. 7A, B), while only $30 \%$ of cell deaths were investigated in the indirect contact coculture system (Fig. 7A, 7B). IL-35 treatment remarkably downregulated the cytotoxicity in both direct and indirect contact systems, with more than $10 \%$ of reduction in cell deaths observed $(P<0.05$, paired $t$-test; Fig. $7 \mathrm{~A}, \mathrm{~B})$. IL-

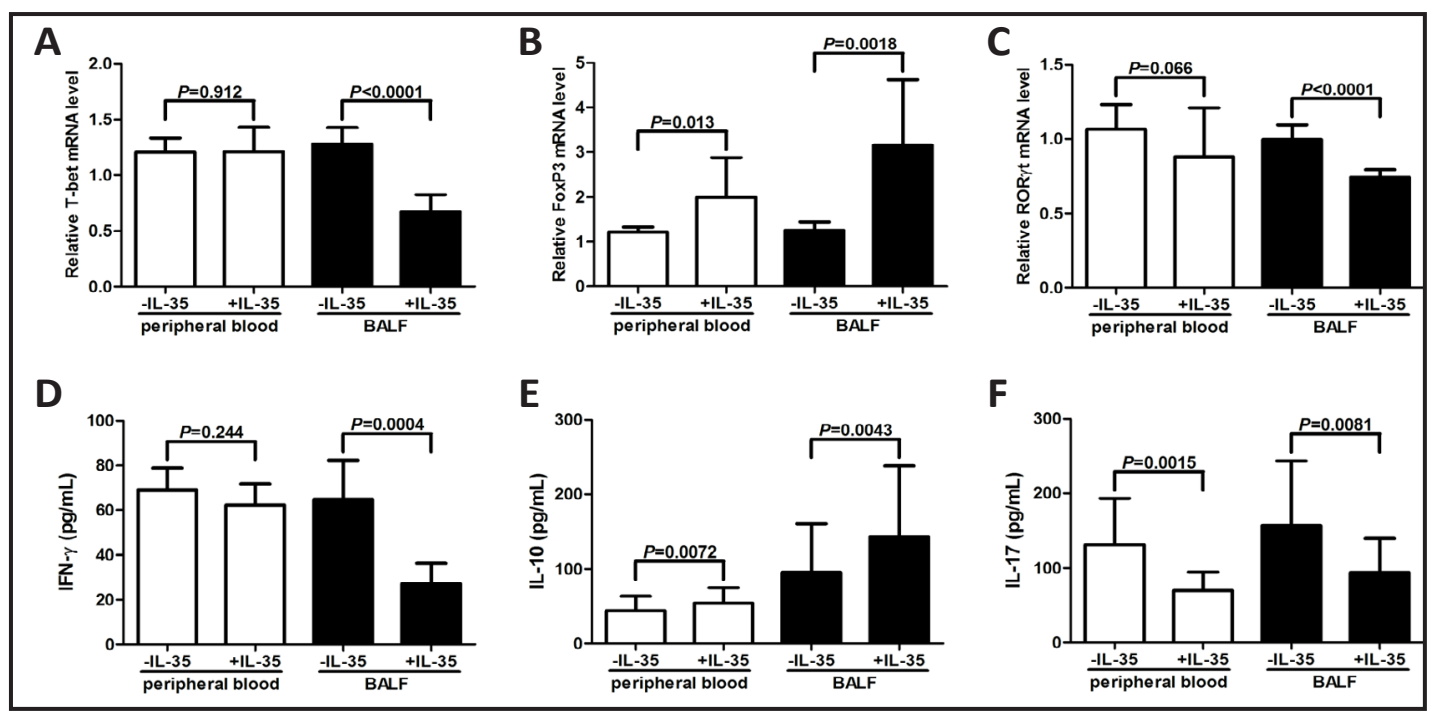

Fig. 4. Effects of interleukin (IL)-35 on the differentiation of $\mathrm{CD} 4^{+} \mathrm{T}$ cells. Purified $\mathrm{CD} 4^{+} \mathrm{T}$ cells from both peripheral blood and bronchoalveolar lavage fluid (BALF) in patients with non-small cell lung cancer were stimulated with recombinant IL-35 for $6 \mathrm{~h}$. Cells and supernatants were harvested for subsequent studies. The mRNA expression of transcription factors including (A) T-bet, (B) FoxP3, and (C) ROR $\gamma \mathrm{t}$ in purified $\mathrm{CD}^{+} \mathrm{T}$ cells was measured by real time polymerase chain reaction. IL-35 stimulation reduced (A) T-bet and (C) ROR $\gamma$ t mRNA expression in BALF CD4 ${ }^{+} \mathrm{T}$ cells, but not in peripheral CD4 ${ }^{+} \mathrm{T}$ cells. In contrast, IL-35 treatment increased (B) FoxP3 mRNA expression in both peripheral and BALF CD4+ $\mathrm{T}$ cells. The expression of (D) interferon- $\gamma$ (IFN- $\gamma$ ), (E) IL-10, and (F) IL-17 in the supernatants was measured by enzyme-linked immunosorbent assay. IL-35 stimulation decreased the expression of (D) IFN- $\gamma$ and (F) IL-17, but elevated (E) IL-10 production from CD4+ T cells.

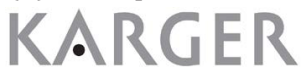


Fig. 5. Effect of interleukin (IL)-35 on the antitumor activity of $\mathrm{CD}^{+} \mathrm{T}$ cells. Purified $\mathrm{CD}^{+}{ }^{+} \mathrm{T}$ cells from both peripheral blood and bronchoalveolar lavage fluid (BALF) of HLA-A2restricted non-small cell lung cancer (NSCLC) patients (including 11 with squamous carcinoma [SCC] and 9 with adenocarcinoma $[\mathrm{AC}]$ ) were stimulated with recombinant IL-35 for $6 \mathrm{~h}$. Cells were washed twice, and were cocultured in direct or indirect contact with stably transfected NSCLC cell lines for $48 \mathrm{~h}$. $\mathrm{CD}^{+}{ }^{+} \mathrm{T}$ cells from patients with SCC were cocultured with NCI-H520 cells, whereas $\mathrm{CD}^{+}{ }^{+} \mathrm{T}$ cells from patients with AC were cocultured with A549 cells. (A and B) The cytotoxicity of $\mathrm{CD} 4^{+} \mathrm{T}$ cells towards target cells was calculated by measuring lactate dehydrogenase concentration in the supernatants. IL-35 stimulation reduced the cytotoxicity of $\mathrm{CD}^{+}{ }^{+} \mathrm{T}$ cells from both peripheral blood (A) and BALF (B) in direct and indirect coculture systems. (C and D) Interferon- $\gamma$ (IFN- $\gamma$ ) and (E and F) tumor necrosis factor- $\alpha$ (TNF- $\alpha$ ) production in the supernatants was measured by enzyme-linked immunosorbent assay. IL-35 stimulation reduced (C and D) IFN- $\gamma$ and (E and F) TNF- $\alpha$ production in the coculture systems.

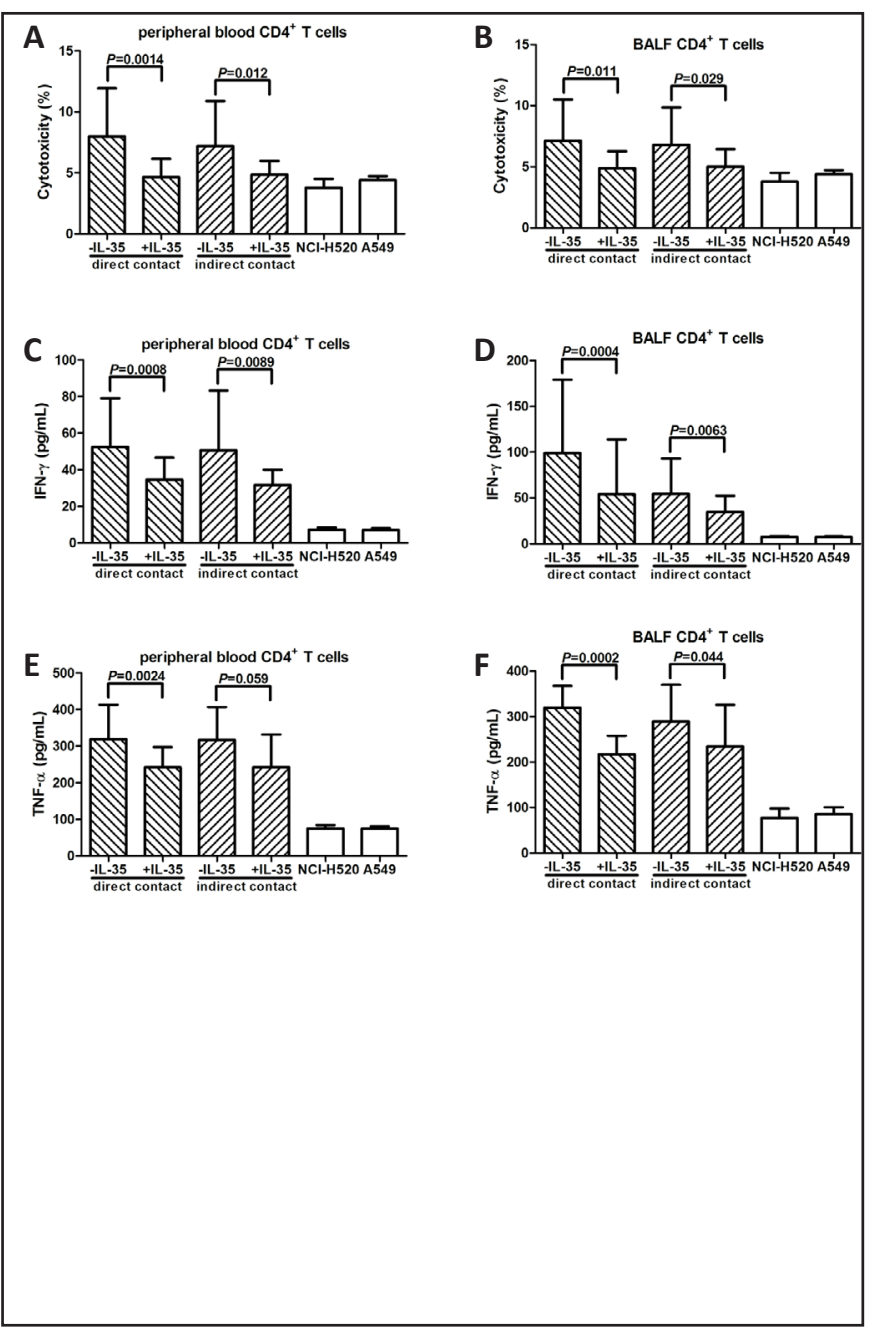

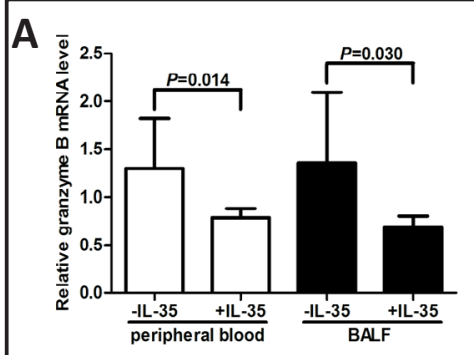
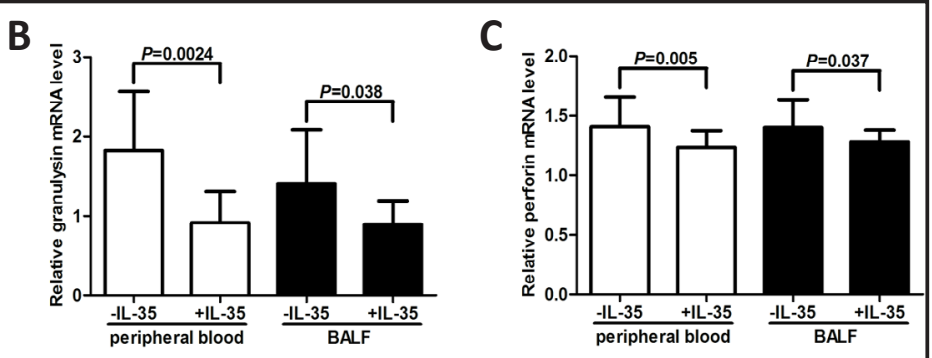

Fig. 6. Effect of interleukin (IL)-35 on the bioactivity of $\mathrm{CD}^{+} \mathrm{T}$ cells. Purified $\mathrm{CD} 8^{+} \mathrm{T}$ cells from both peripheral blood and bronchoalveolar lavage fluid (BALF) in patients with non-small cell lung cancer were stimulated with recombinant IL-35 for $6 \mathrm{~h}$. The mRNA expression of (A) granzyme B, (B) granulysin, and (C) perforin in purified $\mathrm{CD}^{+} \mathrm{T}$ cells was measured by real time polymerase chain reaction. IL-35 stimulation reduced the mRNA expression of granzyme $\mathrm{B}$, granulysin, and perforin in $\mathrm{CD}^{+} \mathrm{T}$ cells.

35 treatment notably decreased both IFN- $\gamma$ and TNF- $\alpha$ production in the supernatant in the direct and indirect coculture systems of $\mathrm{CD}^{+} \mathrm{T}$ cells purified from either peripheral bloods $(P<0.01$, paired $t$-test; Fig. 7C, E) or BALF $(P<0.05$, paired $t$-test; Fig. 7D, F). 


\section{Discussion}

In this study, although there was no statistically significant difference in serum levels of IL-35 between NSCLC patients and healthy individuals, IL35 expression in BALF was significantly higher at the tumor site. In vitro studies have also indicated that recombinant IL35 stimulation did not affect the bioactivity of NSCLC cell lines, but it robustly inhibited the antitumor function of purified $\mathrm{CD} 4^{+}$and $\mathrm{CD} 8^{+}$ $\mathrm{T}$ cells from NSCLC patients. These data suggest that IL-35 mainly exhibits immunosuppressive activity to $\mathrm{T}$ cells, but not to tumor parenchymal cells, in the pathogenesis of NSCLC.

The aberrant expression of IL-35 has been shown in different cancers including acute myeloid leukemia [27, 28], prostate cancer [18], breast cancer [19, 29], colorectal cancer [17, 30], pancreatic ductal adenocarcinoma [31], gastric cancer [32], and hepatocellular carcinoma [33]. $\mathrm{Gu}$ et al [21]. showed that plasma IL-35 expression was elevated and was a promising potential predictor in prognosis of clinical outcome of NSCLC patients. In contrast to the study by $\mathrm{Gu}$ et al., we did not find a remarkable difference in the serum of NSCLC patients, but IL-35 expression at the tumor site was higher than that at the nontumor site. The function of IL-35 in tumor cells has been the subject of debate. An in vitro study by Long et al [34]. showed that overexpression of IL-35 inhibited cell growth and increased apoptosis sensitivity of different human cancer cell lines. In contrast, most studies have demonstrated that IL-35 is an autocrine growth factor [13], which promotes tumor growth through different mechanisms, including enhancement of proliferation and loss of control of tumor cell growth, inhibition of apoptosis, and promotion of angiogenesis, extravasation, and metastasis $[13,15,35,36]$. To the best of our knowledge, the current in vitro results provided the first data about on the influence of IL-35 to bioactivity of NSCLC cell lines. Recombinant IL-35 stimulation did not affect the proliferation, cytokine production, cell cycle, or cellular invasion in either the SCC cell line NCI-520 or AC cell line A549. This

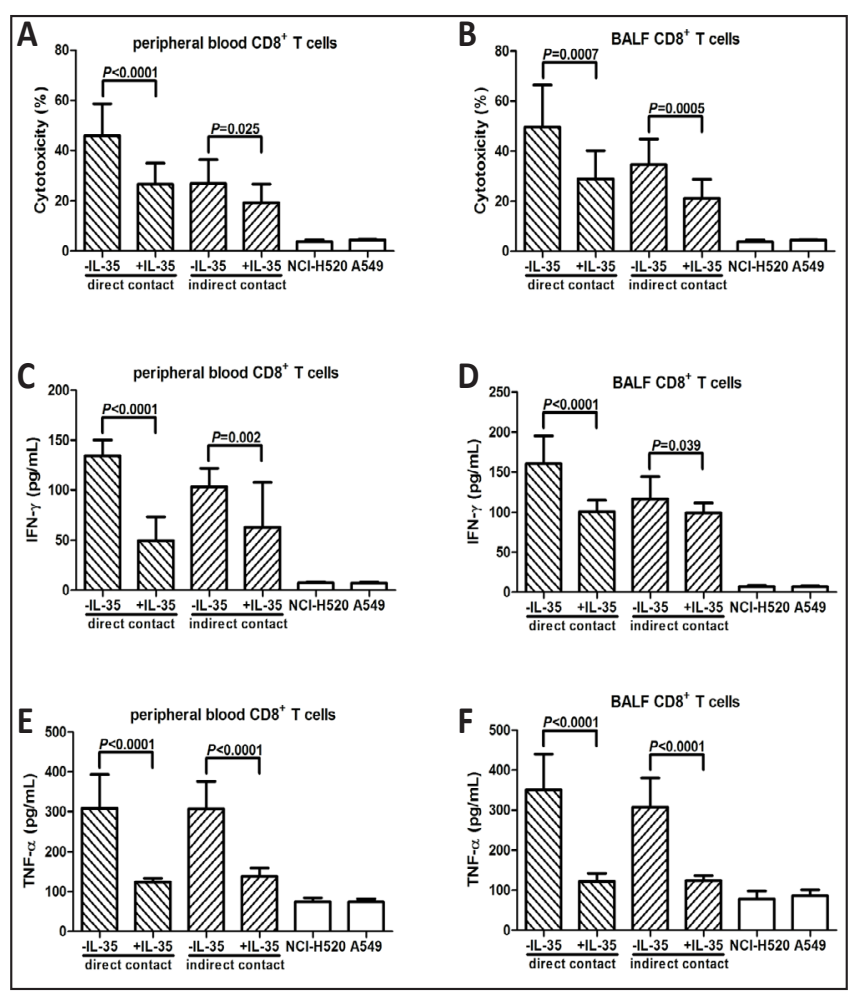

Fig. 7. Effect of interleukin (IL)-35 on the antitumor activity of $\mathrm{CD}^{+} \mathrm{T}$ cells. Purified CD8 ${ }^{+} \mathrm{T}$ cells from both peripheral blood and bronchoalveolar lavage fluid (BALF) of HLA-A2 restricted non-small cell lung cancer (NSCLC) patients (including 11 with squamous carcinoma [SCC] and 9 with adenocarcinoma [AC]) were stimulated with recombinant IL-35 for $6 \mathrm{~h}$. Cells were washed twice, and cocultured in direct or indirect contact with stably transfected NSCLC cell lines for 48 hours. CD8 ${ }^{+} \mathrm{T}$ cells from patients with SCC were cocultured with NCI-H520 cells, while CD8 ${ }^{+} \mathrm{T}$ cells from patients with AC were cocultured with A549 cells. (A and B) The cytotoxicity of $\mathrm{CD}^{+} \mathrm{T}$ cells towards target cells was calculated by measuring lactate dehydrogenase levels in the supernatants. IL-35 stimulation reduced the cytotoxicity of $\mathrm{CD}^{+} \mathrm{T}$ cells from both peripheral blood (A) and BALF (B) in both direct and indirect coculture systems. (C and D) Interferon- $\gamma($ IFN- $\gamma$ ) and ( $E$ and F) tumor necrosis factor- $\alpha$ (TNF- $\alpha$ ) production in the supernatants was measured by enzyme-linked immunosorbent assay. IL-35 stimulation reduced (C and D) IFN- $\gamma$ and ( $E$ and F) TNF- $\alpha$ production in the coculture systems. 
indicated that elevation of IL-35 at the tumor site might not contribute to the growth and metastasis of lung cancer parenchymal cells. However, further in vivo studies are needed to confirm the role of IL-35 in the bioactivity of tumor parenchymal cells.

IL-35 was initially found to be a potent suppressor of proliferation and function of T cells [8]. Thus, we investigated the regulatory functions of IL-35 in both peripheral and lungresident $\mathrm{T}$ cells in patients with NSCLC. IL-35 was shown to expand $\mathrm{CD} 4^{+} \mathrm{CD} 25^{+} \mathrm{FoxP} 3^{+} \mathrm{Tregs}^{-}$ $[11,37]$, and directly suppress IL-17 secretion by Th17 cells [38]. It also inhibited the allergic $\mathrm{CD}^{+} \mathrm{T}$ cells response and modulated Th2-, Tregs-, and Th17-related cytokine production in an allergic rhinitis mouse model [39]. However, few studies have focused on IL-35 regulation of $\mathrm{CD}^{+} \mathrm{T}$ cells in cancers. In this study, we found that IL-35 stimulation increased FoxP3 mRNA and IL-10 secretion and decreased ROR $\gamma$ t mRNA and IL-17 production in CD4+ ${ }^{+}$cells from both peripheral blood and BALF, indicating that IL-35 might also contribute to Treg expansion and Th17 inhibition in patients with NSCLC. However, reduction of T-bet and downregulation of IFN- $\gamma$ was only found in $\mathrm{CD}^{+}{ }^{+} \mathrm{T}$ cells from BALF. Due to the elevation of IL35 expression in BALF but not peripheral blood, it is possible that lung-resident $\mathrm{CD} 4^{+} \mathrm{T}$ cells were sensitized by IL-35, and became more sensitive to IL-35 stimulation. The cytotoxicity of $\mathrm{CD}^{+} \mathrm{T}$ cells was also investigated in both direct and indirect coculture systems with NSCLC cell lines. The direct coculture system can be used to evaluate both the cytolytic and noncytolytic functions of effector T cells, whereas the indirect coculture system can only be used to evaluate noncytolytic effects [23]. Although a previous study demonstrated that human $\mathrm{CD} 4^{+} \mathrm{T}$ cells directly recognized cancer cells and inhibited tumor growth in a cytolytic manner [40], we showed that both cytotoxicity and cytokine production by $\mathrm{CD}^{+} \mathrm{T}$ cells were comparable in direct and indirect systems prior to and post IL-35 stimulation, indicating that it was mostly the cytokine-mediated noncytolytic mechanism that contributed to the anti-tumor activity of CD4 ${ }^{+} \mathrm{T}$ cells. Thus, IL-35 appears to be an important regulator of $\mathrm{CD} 4^{+}$ T cells dysfunction in NSCLC.

The modulatory activity of IL-35 towards $\mathrm{CD}^{+} \mathrm{T}$ cells in NSCLC patients was also investigated. It is well accepted that IL-35 suppresses CD8 ${ }^{+} \mathrm{T}$ cell proliferation [41]. However, the associated regulatory mechanisms are not fully understood. Our in vitro results showed that IL-35 stimulation reduced the mRNA expression of granzyme B, granulysin, and perforin in both peripheral and lung-resident $\mathrm{CD}^{+} \mathrm{T}$ cells in NSCLC patients, suggesting that IL-35 downregulated cytotoxic gene expression in $\mathrm{CD}^{+} \mathrm{T}$ cells. Moreover, the cytotoxicity of CD8 ${ }^{+}$ $\mathrm{T}$ cells reached peak levels with approximately $50 \%$ of cell death observed in the direct coculture system. The cytotoxicity was reduced in the indirect coculture system compared with the direct system, indicating that both cytolytic and noncytolytic characteristics contributed to the cytotoxicity of $\mathrm{CD}^{+} \mathrm{T}$ cells towards tumor cells. Recombinant IL-35 stimulation significantly reduced both IFN $-\gamma$ and TNF- $\alpha$ secretion in both the direct and indirect coculture systems, suggesting that IL-35 suppressed cytokine-induced antitumor immunity against NSCLC. Furthermore, IL-35 also inhibited cytotoxic CD8 ${ }^{+} \mathrm{T}$ cells in the direct coculture system; however, the cytotoxicity was still higher in NSCLC cell lines in indirect contact with $\mathrm{CD}^{+} \mathrm{T}$ cells than that in NSCLC cell lines cultured alone. This indicated that cytokine production by $\mathrm{CD} 8^{+} \mathrm{T}$ cells also demonstrated a cytotoxic effect in target tumor cells.

In summary, IL-35 expression was increased at the tumor site of patients with NSCLC. The elevation of IL-35 displayed immunosuppressive activity towards $\mathrm{CD}^{+}$and $\mathrm{CD}^{+} \mathrm{T}$ cells by reducing their cytolytic and noncytolytic functions; however, it did not affect the bioactivity of NSCLC cell lines in vitro. These data suggest that IL-35 contributes to the dysfunction/exhaustion of T cells and limited antitumor immune responses in NSCLC.

\section{Disclosure Statement}

No conflict of interests exists. 


\section{Cellular Physiology Cell Physiol Biochem 2018;47:2407-2419 \begin{tabular}{l|l} 
DOI: 10.1159/000491615 & $\begin{array}{l}\text { O } 2018 \text { The Author(s). Published by S. Karger AG, Basel } \\
\text { www.karger.com/cpb }\end{array}$
\end{tabular}}

Wang et al.: IL-35 Suppresses T Cells Activity in NSCLC

\section{References}

1 Rahal Z, El Nemr S, Sinjab A, Chami H, Tfayli A, Kadara H: Smoking and Lung Cancer: A Geo-Regional Perspective. Front Oncol 2017;7:194.

- Ferlay J, Soerjomataram I, Dikshit R, Eser S, Mathers C, Rebelo M, Parkin DM, Forman D, Bray F: Cancer incidence and mortality worldwide: sources, methods and major patterns in GLOBOCAN 2012. Int J Cancer 2015;136:E359-386.

-3 Hassanein M, Callison JC, Callaway-Lane C, Aldrich MC, Grogan EL, Massion PP: The state of molecular biomarkers for the early detection of lung cancer. Cancer Prev Res (Phila) 2012;5:992-1006.

-4 Siegel RL, Miller KD, Jemal A: Cancer statistics, 2015. CA Cancer J Clin 2015;65:5-29.

-5 de Mello RA, Veloso AF, Esrom Catarina P, Nadine S, Antoniou G: Potential role of immunotherapy in advanced non-small-cell lung cancer. Onco Targets Ther 2017;10:21-30.

6 Attili I, Passaro A, Pavan A, Conte P, De Marinis F, Bonanno L: Combination immunotherapy strategies in advanced non-small cell lung cancer (NSCLC): Does biological rationale meet clinical needs? Crit Rev Oncol Hematol 2017;119:30-39.

7 Geng Y, Shao Y, He W, Hu W, Xu Y, Chen J, Wu C, Jiang J: Prognostic Role of Tumor-Infiltrating Lymphocytes in Lung Cancer: a Meta-Analysis. Cell Physiol Biochem 2015;37:1560-1571.

8 Collison LW, Workman CJ, Kuo TT, Boyd K, Wang Y, Vignali KM, Cross R, Sehy D, Blumberg RS, Vignali DA: The inhibitory cytokine IL-35 contributes to regulatory T-cell function. Nature 2007;450:566-569.

-9 Niedbala W, Wei XQ, Cai B, Hueber AJ, Leung BP, McInnes IB, Liew FY: IL-35 is a novel cytokine with therapeutic effects against collagen-induced arthritis through the expansion of regulatory $\mathrm{T}$ cells and suppression of Th17 cells. Eur J Immunol 2007;37:3021-3029.

10 Tedder TF, Leonard WJ: Autoimmunity: regulatory B cells--IL-35 and IL-21 regulate the regulators. Nat Rev Rheumatol 2014;10:452-453.

11 Castellani ML, Anogeianaki A, Felaco P, Toniato E, De Lutiis MA, Shaik B, Fulcheri M, Vecchiet J, Tete S, Salini V, Theoharides TC, Caraffa A, Antinolfi P, Frydas I, Conti P, Cuccurullo C, Ciampoli C, Cerulli G, Kempuraj D: IL-35, an anti-inflammatory cytokine which expands CD4+CD25+ Treg Cells. J Biol Regul Homeost Agents 2010;24:131-135.

12 Jiang S, Li Y, Lin T, Yuan L, Li Y, Wu S, Xia L, Shen H, Lu J: IL-35 Inhibits Angiogenesis through VEGF/Ang2/ Tie2 Pathway in Rheumatoid Arthritis. Cell Physiol Biochem 2016;40:1105-1116.

13 Nicholl MB, Ledgewood CL, Chen X, Bai Q Qin C, Cook KM, Herrick EJ, Diaz-Arias A, Moore BJ, Fang Y: IL35 promotes pancreas cancer growth through enhancement of proliferation and inhibition of apoptosis: evidence for a role as an autocrine growth factor. Cytokine 2014;70:126-133.

14 Friedman A, Liao KL: The role of the cytokines IL-27 and IL-35 in cancer. Math Biosci Eng 2015;12:12031217.

15 Liao KL, Bai XF, Friedman A: Mathematical modeling of Interleukin-35 promoting tumor growth and angiogenesis. PLoS One 2014;9:e110126.

16 Turnis ME, Sawant DV, Szymczak-Workman AL, Andrews LP, Delgoffe GM, Yano H, Beres AJ, Vogel P, Workman CJ, Vignali DA: Interleukin-35 Limits Anti-Tumor Immunity. Immunity 2016;44:316-329.

-17 Zhang J, Mao T, Wang S, Wang D, Niu Z, Sun Z, Zhang J: Interleukin-35 expression is associated with colon cancer progression. Oncotarget 2017;8:71563-71573.

-18 Zhou C, Zhang J, Chen Y, Wang H, Hou J: Interleukin-35 as a predictor of prostate cancer in patients undergoing initial prostate biopsy. Onco Targets Ther 2017;10:3485-3491.

19 Zhao Z, Chen X, Hao S, Jia R, Wang N, Chen S, Li M, Wang C, Mao H: Increased interleukin-35 expression in tumor-infiltrating lymphocytes correlates with poor prognosis in patients with breast cancer. Cytokine 2017;89:76-81.

20 Long J, Guo H, Cui S, Zhang H, Liu X, Li D, Han Z, Xi L, Kou W, Xu J, Li TS, Ding Y: IL-35 expression in hepatocellular carcinoma cells is associated with tumor progression. Oncotarget 2016;7:45678-45686.

21 Gu X, Tian T, Zhang B, Liu Y, Yuan C, Shao L, Guo Y, Fan K: Elevated plasma interleukin-35 levels predict poor prognosis in patients with non-small cell lung cancer. Tumour Biol 2015;36:2651-2656.

22 Britten CM, Meyer RG, Kreer T, Drexler I, Wolfel T, Herr W: The use of HLA-A*0201-transfected K562 as standard antigen-presenting cells for CD8(+) T lymphocytes in IFN-gamma ELISPOT assays. J Immunol Methods 2002;259:95-110. 


\section{Cellular Physiology Cell Physiol Biochem 2018;47:2407-2419 \begin{tabular}{l|l} 
DOI: 10.1159/000491615 & $\begin{array}{l}\text { O } 2018 \text { The Author(s). Published by S. Karger AG, Basel } \\
\text { www.karger.com/cpb }\end{array}$
\end{tabular}}

Wang et al.: IL-35 Suppresses T Cells Activity in NSCLC

23 Phillips S, Chokshi S, Riva A, Evans A, Williams R, Naoumov NV: CD8(+) T cell control of hepatitis B virus replication: direct comparison between cytolytic and noncytolytic functions. J Immunol 2010;184:287-295.

-24 Qin L, Zhou YC, Wu HJ, Zhuo Y, Wang YP, Si CY, Qin YM: Notch Signaling Modulates the Balance of Regulatory T Cells and T Helper 17 Cells in Patients with Chronic Hepatitis C. DNA Cell Biol 2017;36:311-320.

25 Lugo-Villarino G, Maldonado-Lopez R, Possemato R, Penaranda C, Glimcher LH: T-bet is required for optimal production of IFN-gamma and antigen-specific T cell activation by dendritic cells. Proc Natl Acad Sci U S A 2003;100:7749-7754.

26 Madsen CB, Norgaard A, Iversen M, Ryder LP: Elevated mRNA levels of CTLA-4, FoxP3, and granzyme B in BAL, but not in blood, during acute rejection of lung allografts. Transpl Immunol 2010;24:26-32.

-27 Wu H, Li P, Shao N, Ma J, Ji M, Sun X, Ma D, Ji C: Aberrant expression of Treg-associated cytokine IL-35 along with IL-10 and TGF-beta in acute myeloid leukemia. Oncol Lett 2012;3:1119-1123.

28 Wang J, Tao Q, Wang H, Wang Z, Wu F, Pan Y, Tao L, Xiong S, Wang Y, Zhai Z: Elevated IL-35 in bone marrow of the patients with acute myeloid leukemia. Hum Immunol 2015;76:681-686.

29 Chen G, Liang Y, Guan X, Chen H, Liu Q, Lin B, Chen C, Huang M, Chen J, Wu W, Liang Y, Zhou K, Zeng J: Circulating low IL-23: IL-35 cytokine ratio promotes progression associated with poor prognosisin breast cancer. Am J Transl Res 2016;8:2255-2264.

- 30 Zeng JC, Zhang Z, Li TY, Liang YF, Wang HM, Bao JJ, Zhang JA, Wang WD, Xiang WY, Kong B, Wang ZY, Wu BH, Chen XD, He L, Zhang S, Wang CY, Xu JF: Assessing the role of IL-35 in colorectal cancer progression and prognosis. Int J Clin Exp Pathol 2013;6:1806-1816.

-31 Jin P, Ren H, Sun W, Xin W, Zhang H, Hao J: Circulating IL-35 in pancreatic ductal adenocarcinoma patients. Hum Immunol 2014;75:29-33.

-32 Fan YG, Zhai JM, Wang W, Feng B, Yao GL, An YH, Zeng C: IL-35 over-expression is associated with genesis of gastric cancer. Asian Pac J Cancer Prev 2015;16:2845-2849.

-33 Fu YP, Yi Y, Cai XY, Sun J, Ni XC, He HW, Wang JX, Lu ZF, Huang JL, Cao Y, Zhou J, Fan J, Qiu SJ: Overexpression of interleukin-35 associates with hepatocellular carcinoma aggressiveness and recurrence after curative resection. Br J Cancer 2016;114:767-776.

34 Long J, Zhang X, Wen M, Kong Q, Lv Z, An Y, Wei XQ: IL-35 over-expression increases apoptosis sensitivity and suppresses cell growth in human cancer cells. Biochem Biophys Res Commun 2013;430:364-369.

-35 Wang Z, Liu JQ, Liu Z, Shen R, Zhang G, Xu J, Basu S, Feng Y, Bai XF: Tumor-derived IL-35 promotes tumor growth by enhancing myeloid cell accumulation and angiogenesis. J Immunol 2013;190:2415-2423.

-36 Huang C, Li N, Li Z, Chang A, Chen Y, Zhao T, Li Y, Wang X, Zhang W, Wang Z, Luo L, Shi J, Yang S, Ren H, Hao J: Tumour-derived Interleukin 35 promotes pancreatic ductal adenocarcinoma cell extravasation and metastasis by inducing ICAM1 expression. Nat Commun 2017;8:14035.

-37 Liu S, Zhang Q, Shao X, Wang W, Zhang C, Jin Z: An immunosuppressive function of interleukin-35 in chronic hepatitis C virus infection. Int Immunopharmacol 2017;50:87-94.

-38 Okada K, Fujimura T, Kikuchi T, Aino M, Kamiya Y, Izawa A, Iwamura Y, Goto H, Okabe I, Miyake E, Hasegawa Y, Mogi M, Mitani A: Effect of interleukin (IL)-35 on IL-17 expression and production by human CD4+ T cells. PeerJ 2017;5:e2999.

-39 Yokota M, Suzuki M, Nakamura Y, Ozaki S, Murakami S: Cytokine modulation by IL-35 in mice with allergic rhinitis. Am J Rhinol Allergy 2015;29:251-256.

-40 Matsuzaki J, Tsuji T, Luescher IF, Shiku H, Mineno J, Okamoto S, Old LJ, Shrikant P, Gnjatic S, Odunsi K: Direct tumor recognition by a human CD4(+) T-cell subset potently mediates tumor growth inhibition and orchestrates anti-tumor immune responses. Sci Rep 2015;5:14896.

41 Song M, Ma X: The Immunobiology of Interleukin-35 and Its Regulation and Gene Expression. Adv Exp Med Biol 2016;941:213-225. 